\begin{tabular}{|l|l|}
\hline JITAS & $\begin{array}{l}\text { JANHUS Journal of Animal Husbandry Science } \\
\text { Jurnal Ilmu Peternakan } \\
\text { Fakultas Pertanian, Universitas Garut } \\
\text { ISSN : 2548-7914 }\end{array}$ \\
\hline
\end{tabular}

\title{
PENGARUH FERMENTASI LIMBAH ISI GIZZARD (LIGAB) DAN DEDAK DENGAN Trichoderma TERHADAP KADAR AIR DAN PROTEIN KASAR
}

\section{(The Effect of Waste Content Fermentation of Gizzard and Rice Bran with Trichoderma against Water Content and Crude Protein)}

\author{
Deni Ginanjar ${ }^{1}$, Titin Nurhayatin ${ }^{2}$ dan Ervi Herawati ${ }^{3}$ \\ ${ }^{1,2,3}$ Program Studi Peternakan Fakultas Pertanian Universitas Garut \\ Jl. Raya Samarang No. 52.A Tarogong Kaler Garut 44151
}

Email:

deniginanjar56@gmail.com

titinnurhayatin36@yahoo.com

erviherawati@uniga.ac.id

\begin{abstract}
Abstrak
Penelitian ini bertujuan untuk mengetahui pengaruh fermentasi limbah isi gizzard dan dedak padi dengan Trichoderma terhadap kadar air dan protein kasar. Penelitian dilaksanakan di Laboratorium Terpadu Universitas Garut dan Laboratorium Nutrisi dan Kimia Makanan Ternak Fakultas Peternakan Universitas Padjadjaran. Metode yang digunakan adalah metode eksperimental dengan menggunakan Rancangan acak lengkap (RAL), menggunakan 5 perlakuan dan 4 ulangan, perlakuan terdiri dari : $\mathrm{P} 1=90 \% \mathrm{LIGAB}+5 \%$ dedak $+5 \%$ Trichoderma, $\mathrm{P} 2=85 \%$ LIGAB $+10 \%$ dedak $+5 \%$ Trichoderma, $\mathrm{P} 3=80 \%$ LIGAB $+15 \%$ dedak $+5 \%$ Trichoderma, $\mathrm{P} 4=$ 75\% LIGAB $+20 \%$ dedak $+5 \%$ Trichoderma, $\mathrm{P} 5=70 \%$ LIGAB $+25 \%$ dedak $+5 \%$ Trichoderma. Hasil penelitian menunjukkan bahwa perlakuan P5 dapat menurunkan kadar air dan meningkatkan protein kasar bahan pakan.
\end{abstract}

Kata kunci: fermentasi, isi gizzard, dedak, Trichoderma, protein

\begin{abstract}
This study aims to determine the effect of fermentation of waste content of gizzard and rice bran with Trichoderma to water content and crude protein. The research was conducted in Integrated Laboratory of Garut University and Animal Feed and Nutrition Laboratory of Faculty of Animal Husbandry of University Padjadjaran Jatinangor. The method used was experimental method using Completely Randomized Design with 5 treatments and 4 replications. Treatment consist of $P 1=90 \%$ LIGAB $+5 \%$ rice bran $+5 \%$ Trichoderma, $P 2=85 \%$ LIGAB $+10 \%$ rice bran $+5 \%$ Trichoderma, $P 3=80 \%$ LIGAB $+15 \%$ rice bran $+5 \%$ Trichoderma, $P 4=75 \%$ LIGAB $+20 \%$ rice bran $+5 \%$ Trichoderma, $P 5=70 \%$ LIGAB $+25 \%$ rice bran $+5 \%$ Trichoderma. The result eksperimen showed is treatment P5 showed decrease water content and increase protein content feed ingredients.
\end{abstract}

Keywords: fermentation, gizzard content, rice bran, Trichoderma, protein 


\section{Pendahuluan}

Ketersediaan bahan pakan ternak semakin terbatas dikarenakan meningkatnya harga bahan baku pakan, dan bersaing dengan manusia. Oleh karena itu, sumber bahan pakan baru yang mampu mensubstitusi sebagian bahan pakan dalam ransum perlu dicari, sehingga dapat menekan biaya pakan. Bahan tersebut harus tersedia dalam jumlah banyak, dan tidak membutuhkan biaya besar. Limbah isi gizzard ayam broiler (LIGAB) cukup banyak seiring dengan berkembangnya usaha ayam broiler. Sehingga limbah ini berpotensi untuk diadikan bahan pakan. Menurut Deni (2017) menyatakan bahwa kandungan nutrient LIGAB memiliki kadar air 62,70\%, kadar abu 4,36\%, serat kasar 6,63\% dan kadar protein kasar sebesar 15,49\%. Namun demikian LIGAB mempunyai keterbatasan, antara lain bersifat voluminous dan berkadar air tinggi.

Menurut Mukodiningsih (2003) umumnya limbah hewan mengandung banyak air, sehingga dalam pencampuran perlu dikurangi kadar airnya sebelum dicampur dalam pakan atau diberikan langsung pada ternak. Oleh kareana itu, perlu dilakukan pengolahan ataupun perlakuan dapat awet dan nilai gizinya bertambah. Teknologi fermentasi anaerob dari LIGAB menjadi alternatif teknologi pengolahan pakan serta dapat dilakukan oleh peternak itu sendiri, sehingga dapat menghemat waktu dan biaya pakan. Fermentasi juga dapat dijadikan sebagai sumber probiotik dan asam organik. Keuntungan lain yaitu dari segi penyimpanan lebih tahan lama karena bakteri-bakteri pembusuk tidak tahan terhadap $\mathrm{pH}$ rendah, bakteri pembusuk akan terhambat pertumbuhannya sehingga ketersediaan, kualitas dan harga pakan dapat terjamin.

Kualitas fermentasi anaerob isi gizzard ayam broiler sangat ditentukan oleh bahan yang ditambahkan. Salah satu bahan yang dapat digunakan sebagai aditif dalam pengolahan limbah hewan adalah dedak. Dedak padi memiliki bau khas wangi dedak, jika baunya sudah tengik berarti telah terjadi reaksi kimia (Dharmawati et al. 2014). Dedak dalam pembuatan silase berfungsi sebagai sumber karbohidrat merupakan substrat bagi bakteri asam laktat dan menghasilkan senyawa asam terjadi penurunan $\mathrm{pH}$, sehingga mematikan bakteri pembusuk maupun bakteri patogen tidak dapat tumbuh (Nunung 2012).

Penambahan dedak pada proses fermentasi dapat mengurangi kadar air limbah isi gizzard ayam sehingga tidak mudah busuk, karena dedak bersifat menyerap air/bersifat hidrofilik. Dikemukakan Schalbroeck (2001) bahwa fungsi dedak dalam fermentasi adalah sebagai bahan pemadat dan pengikat sehingga bentuk produk hasil fermentasi akan menarik, disamping itu penambahan dedak dalam substrat akan dimanfaatkan oleh mikroorganisme sebagai sumber energi untuk pertumbuhan dan perkembangannya, sehingga menyebabkan mikroba cepat tumbuh dan mudah berkembang biak.

Penelitian Palupi dan Imsya (2011) mengenai pemanfaatan Trichoderma dalam proses fermentasi limbah udang sebagai pakan ternak unggas menunjukan bahwa pemberian inokulum Trichoderma dengan dosis $4 \%$ dengan lama fermentasi 48 jam meningkatkan kualitas dan daya cerna protein, kandungan protein kasar tepung limbah udang fermentasi sebesar $41,27 \%$ dengan daya cerna protein $81,24 \%$. Oleh karena itu, penulis tertarik untuk melakukan penelitian mengenai "Pengaruh fermentasi limbah isi gizzard (LIGAB) dan dedak dengan trichoderma terhadap Kadar air dan protein kasar"

\section{Metodologi}

\subsection{Waktu dan Tempat}


Penelitian telah dilaksanakan di Laboratorium Terpadu Universitas Garut dan Laboratorium Nutrisi dan Kimia Makana Ternak Fakultas Peternakan Universitas Padjadjaran Jatinangor, mulai bulan Agustus sampai Oktober 2017.

\subsection{Bahan dan Metoda Penelitian}

\section{Bahan Penelitian}

Bahan yang digunakan dalam penelitian, yaitu :

1. Limbah isi gizzard ayam broiler di dapat dari tempat pemotongan ayam di Kampung Cibanen Desa Sukaraja Kecamatan Cibugel Kabupaten Sumedang.

2. Dedak padi dari pabrik penggilingan padi di Kampung Samanggen Desa Wanaraja Kecamatan Wanaraja Kabupaten Garut

3. Trichoderma diperoleh dari IKA Maja Wanaraja Kabupaten Garut.

\section{Metode Penelitian}

Metode yang digunakan dalam penelitian adalah eksperimental dengan menggunakan Rancangan Acak Lengkap dengan 5 perlakuan yang diulang 4 kali. Perlakuan tersebut sebagai berikut : $\mathrm{P} 1=5 \%$ Trichoderma $+5 \%$ dedak padi $+90 \%$ LIGAB, $\mathrm{P} 2=5 \%$ Trichoderma $+10 \%$ dedak padi $+85 \%$ LIGAB. P3 $=5 \%$ Trichoderma $+15 \%$ dedak padi $+80 \%$ LIGAB, P $4=5 \%$ Trichoderma $+20 \%$ dedak padi $+75 \%$ LIGAB, P5 $=5 \%$ Trichoderma $+25 \%$ dedak padi $+70 \%$ LIGAB.

Peubah yang diamati adalah kadar air dan kadar protein kasar. Pengukuran air hasil fermentasi anaerob LIGAB dilakukan dengan mengambil sampel sebanyak tiga sampel dengan masing-masing berat 10 gram, selanjutnya dilakukan pengovenan. Kadar air dihitung dengan cara perhitungan bobot asal dikurangi bobot setelah dioven. Selisih dari bobot tersebut merupakan kadar air yang dihitung dengan persen. Kadar Protein kasar dihitung dengan menggunakan metode Kjheldal.

\section{Hasil dan Pembahasan}

\section{Pengaruh Perlakuan Fermentasi LIGAB terhadap Kandungan Air}

Kadar air merupakan salah satu syarat untuk terjadinya proses fermentasi yang optimal, kadar air yang oftimal dapat menghasilkan fermentasi yang berjalan dengan baik. Rata-rata kadar air LIGAB terfermentasi dapat dilihat pada Tabel 1.

Tabel 1. Pengaruh Perlakuan Fermentasi LIGAB terhadap Kandungan Air (\%)

\begin{tabular}{cccccc}
\hline Ulangan & \multicolumn{5}{c}{ Perlakuan } \\
\cline { 2 - 6 } & P1 & P2 & P3 & P4 & \\
\hline I & 48,86 & 44,05 & 46,94 & 40,42 & 36,29 \\
II & 44,57 & 42,62 & 43,40 & 41,35 & 38,20 \\
III & 45,78 & 43,04 & 42,45 & 41,35 & 40,34 \\
IV & 44,25 & 44,20 & 40,64 & 40,70 & 39,40 \\
\hline Total & 45,87 & 43,48 & 43,36 & 40,96 & 38,56 \\
\hline
\end{tabular}


Keterangan :

$\mathrm{P} 1=5 \%$ Trichoderma $+5 \%$ dedak padi $+90 \%$ LIGAB

$\mathrm{P} 2=5 \%$ Trichoderma $+10 \%$ dedak padi $+85 \%$ LIGAB

$\mathrm{P} 3=5 \%$ Trichoderma $+15 \%$ dedak padi $+80 \%$ LIGAB

$\mathrm{P} 4=5 \%$ Trichoderma $+20 \%$ dedak padi $+75 \%$ LIGAB

$\mathrm{P} 5=5 \%$ Trichoderma $+25 \%$ dedak padi $+70 \%$ LIGAB

Data di atas menunjukan adanya nilai rataan kadar air yang berbeda. Nilai rataan kadar air terendah ada pada P5 dengan nilai 36,29\% dan yang tertinggi pada P1 yaitu sebesar 48,86\%. Untuk melihat pengaruh perlakuan terhadap kadar air maka dilakukanlah analisis ragam. Hasil analisis Ragam menunjukkan Fhit $(10,11)>$ Ftabel $0.05(3,48)$ yang berarti bahwa penambahan dedak padi dan Trichoderma memberikan pengaruh yang berbeda nyata terhadap Kadar Air fermentasi LIGAB. Hasil analisis lanjutan rata-rata kadar air fermentasi LIGAB dengan menggunakan uji beda rata-rata menggunakan Uji Jarak Berganda Duncan pada taraf nyata $5 \%$. Untuk melihat perbedaan antar perlakuan hasil analisisnya disajikan pada Tabel 2.

Tabel 2. Analisis Uji Jarak Berganda Duncan Pengaruh Fermentasi LIGAB dan Dedak Padi dengan Trichoderma terhadap Kadar Air

\begin{tabular}{ccc}
\hline Perlakuan & Rataan Kadar Air $(\%)$ & Signifikansi \\
\hline P1 & 45,87 & $\mathrm{c}$ \\
P2 & 43,48 & $\mathrm{bc}$ \\
P3 & 43,36 & $\mathrm{bc}$ \\
P4 & 40,96 & $\mathrm{ab}$ \\
P5 & 38,56 & $\mathrm{a}$ \\
\hline
\end{tabular}

Keterangan : Angka rata-rata yang diikuti huruf sama pada kolom, tidak berbeda nyata berdasarkan Uji Jarak Berganda Duncan pada taraf nyata 5\%

Tabel 2 memperlihatkan bahwa semakin banyak penambahan dedak padi yang digunakan semakin menurun pula kadar air yang didadapat, hal ini didukung oleh Gunawan (2005) yang menyatakan bahwa penambahan dedak dalam substrat akan dimanfaatkan oleh mikroorganisme seperti Trichoderma sebagai sumber energi untuk pertumbuhan dan perkembangannya, sehingga menyebabkan mikroba cepat tumbuh dan mudah berkembang biak dan mempercepat proses fermentasi.

Tingginya kadar air pada perlakuan dengan penambahan dedak yang sedikit ( $\mathrm{P} 1=5 \%$ dedak padi) disebabkan dedak yang sedikit kurang mampu menyerap kandungan air dari bahan pakan limbah isi gizzard ayam selama proses fermentasi, sebaliknya dengan penambahan dedak yang lebih besar kandungan air lebih banyak diserap, dimana dedak dapat mengurangi kadar air karena bersifat menyerap air/bersifat hidrofilik. Fungsi dedak dalam fermentasi adalah sebagai bahan pemadat dan pengikat.

Menurut Abun dan Rusmana (2005) bahan pakan atau ransum berkadar air tinggi (40-70\%) yang difermentasi dalam kondisi anaerob selama waktu tertentu dikatakan baik jika mempunyai pH 3-4, bau asam (didominasi oleh asam laktat), tidak berjamur mempunyai warna seperti atau mendekati warna bahan pakan atau ransum sebelum difermentasi, mengandung bakteri asam laktat lebih dari 106, dan mempunyai nilai gizi yang hampir sama dengan bahan asalnya karena kehilangan bahan kering selama proses fermentasi sangat sedikit. Bahan pakan hasil fermentasi anaerob yang baik dapat bertahan lama bila disimpan dalam kondisi anaerob tanpa secara nyata menurunkan nilai gizinya. 


\section{Pengaruh Perlakuan Fermentasi LIGAB terhadap Kadar Protein Kasar}

Kadar protein kasar adalah semua zat yang mengandung nitrogen yang terdapat dalam bahan pakan Fermentasi LIGAB. Rata-rata kadar protein kasar Fermentasi LIGAB dapat dilihat pada Tabel 3.

Tabel 3. Pengaruh Perlakuan Fermentasi LIGAB terhadap kadar Protein Kasar (\%)

\begin{tabular}{cccccr}
\hline \multirow{2}{*}{ Ulangan } & \multicolumn{5}{c}{ Perlakuan } \\
\cline { 2 - 6 } & P1 & P2 & P3 & P4 & \\
\hline I & 13,32 & 14,25 & 14,74 & 15,50 & 15,47 \\
II & 13,45 & 14,15 & 14,83 & 15,10 & 15,38 \\
III & 13,53 & 14,12 & 14,63 & 14,90 & 15,57 \\
IV & 13,72 & 13,90 & 14,78 & 15,22 & 15,15 \\
\hline Rataan & 13,51 & 14,11 & 14,75 & 15,18 & 15,39 \\
\hline
\end{tabular}

Tabel 3 menyatakan bahwa semakin banyak dedak yang digunakan maka semakin meningkat pula kadar protein kasar Fermentasi LIGAB, hal ini dapat dilihat dari P1 yang memiliki nilai rataan kadar protein kasar sebesar 13,51\% dan semakin meningkat pada P5 yang memiliki kadar protein kasar rataan terbesar sebesar 15,39\%. Untuk melihat pengaruh perlakuan terhadap protein kasar maka dilakukanlah analisis ragam. Hasil analisis Ragam menunjukkan Fhit $(79,82)$ $>$ Ftabel $0.05(3,48)$ yang berarti bahwa penambahan dedak padi dan Trichoderma memberikan pengaruh yang berbeda nyata terhadap kadar protein kasar fermentasi LIGAB. Hasil analisis lanjutan rata-rata kadar protein kasar fermentasi LIGAB dengan menggunakan uji beda rata-rata menggunakan Uji Jarak Berganda Duncan pada taraf nyata 5\%. Hasil analisisnya disajikan pada Tabel 4.

Tabel 4. Analisis Uji Jarak Berganda Duncan Pengaruh Fermentasi LIGAB dan Dedak Padi dengan Trichoderma terhadap Kadar Protein Kasar

\begin{tabular}{ccc}
\hline Perlakuan & Rataan Kadar Air $(\%)$ & Signifikansi \\
\hline P1 & 13,51 & $\mathrm{a}$ \\
P2 & 14,11 & $\mathrm{~b}$ \\
P3 & 14,75 & $\mathrm{c}$ \\
P4 & 15,18 & $\mathrm{~d}$ \\
P5 & 15,39 & $\mathrm{~d}$ \\
\hline
\end{tabular}

Keterangan : Angka rata-rata yang diikuti huruf sama pada kolom, tidak berbeda nyata berdasarkan Uji Jarak Berganda Duncan pada taraf nyata 5\%

Tabel 4. menunjukkan bahwa pengaruh pemberian dedak padi dan Trichoderma terhadap kadar protein kasar bahan pakan Fermentasi LIGAB, perlakuan yang dicoba menunjukkan perbedaan yang nyata dimana semua perlakuan menunjukkan pengaruh yang berbeda nyata, kecuali perlakuan P4 dan P5 menunjukkan pengaruh yang tidak berbeda nyata. Kadar protein kasar tertinggi terdapat pada perlakuan P5 (5\% Trichoderma $+25 \%$ dedak padi $+70 \%$ limbah isi gizzard ayam broiler) yaitu $15,39 \%$ sedangkan kadar protein kasar terendah terjadi pada perlakuan P1 (5\% Trichoderma $+5 \%$ dedak padi $+90 \%$ limbah isi gizzard ayam broiler) yaitu sebesar $13,51 \%$.

Berbedanya kadar protein kasar antara perlakuan disebabkan adanya penambahan dedak dan Trichoderma, sehingga memberi kemungkinan yang lebih baik bagi mikroba untuk tumbuh dan berkembangbiak. Meningkatnya jumlah mikroba maka kadar protein kasar bahan pakan 
LIGAB akan mengalami peningkatan, karena mikroba merupakan sumber protein sel tunggal yang nantinya akan berpengaruh terhadap hasil fermentasi anaerob. Menurut Mendoza et al. (1994) bahwa dalam proses fermentasi terjadi peningkatan protein kasar yang diakibatkan oleh terbentuknya protein sel tunggal pada saat dan setelah fermentasi.

Perlakuan yang menggunakan bahan tambahan dedak padi yang lebih tinggi dapat meningkatkan kadar protein kasar. Hal ini disebabkan pada bahan tambahan dedak halus kandungan proteinnya tinggi dan kandungan protein tersebut nantinya akan berinteraksi dengan produk bahan pakan LIGAB. Kandungan protein erat hubungannya dengan kandungan serat kasar, dimana makin tinggi kandungan protein dari jenis bahan pakan yang sama, makin rendah kandungan serat kasarnya. Bahan yang mengandung protein juga lebih mudah dicerna dibandingkan bahan yang mengandung serat kasar. Jadi bila kandungan protein dari bahan pakan tinggi dan serat kasarnya rendah akan lebih mudah dicerna dibandingkan sebaliknya (Tillman $d k k ., 1991)$.

\section{$4 \quad$ Kesimpulan}

Fermentasi limbah isi gizzard ayam broiler dan dedak padi dengan Trichoderma berpengaruh terhadap kandungan air dan protein kasar. Campuran $70 \%$ limbah isi gizzard ayam broiler $+25 \%$ dedak padi $+5 \%$ Trichoderma $(\mathrm{P} 5)$ dapat menghasilkan fermentasi limbah isi gizzard ayam broiler yang baik, yaitu menurunkan kadar air dan meningkatkan kadar protein bahan pakan.

\section{$5 \quad$ Daftar Pustaka}

Abun dan Rusmana. 2005. Efek Ransum Mengandung Ampas Umbi Garut Produk Fermentasi oleh Kapang Aspergillus niger terhadap Imbangan Efisiensi Protein dan Konversi Ransum pada Ayam Broiler. Laporan Penelitian. Fakultas Peternakan Universitas Padjadjaran.

Deni Ginanjar. 2017. Kandungan Nutrient Limbah Isi Gizzard Ayam Broiler. Hasil Analisis Laboratorium Nutrisi dan Kimia Makanan Ternak Fakultas Peternakan Universitas Padjadjaran. Jatinangor.

Dharmawati, S., S.Djaya, dan A. Setiawan. 2014. Kualitas Protein dan Serat Kasar Silase Keong Rawa "Kalambuai" yang Menggunakan Sumber Aditif Dedak dan Onggok dengan Pemanfaatan Saccharomyces Cerevisiae. Fakultas Pertanian Jurusan Peternakan Universitas Islam Kalimantan, Banjarmasin.

Gunawan. 2005. Percobaan Membuat Inokulum untuk Tempe dan Oncom. LIPI Bandung

Mendoza, N. S., M. Arai, T. Kawaguchi, F. S. Cubol, E. G. Panerio, T. Yoshida, and L. M. Jonson. 1994. Isolation of Mannanutilizing Bacteria and the Culture Conditions for Mannanase Production. World Joumal of Microbiology and Biotechnology, 10 (1) : 51-54.. Meirizal dan Edi Irawan (2008).

Mukodiningsih S., Sulistyanto, and Yunianto. 2003. The Rice Brand Filler Supplementation in Drying Fish Silage and Its Effect on Crude Protein and Nitrogen Free Extract. International seminar: Functional Foods and Nutraceuticals Based on Marine Products. Bogor. 
Nunung A. 2012. Silase Ikan untuk Pakan Ternak. Dinas Peternakan Sulawesi Selatan, Makassar.

Palupi dan A. Imsya. 2011. Pemanfaatan Kapang Trichoderma viridae dalam Proses Fermentasi untuk Meningkatkan Kualitas dan Daya Cerna Protein Limbah Udang sebagai Pakan Ternak Unggas. Seminar Nasional Teknologi Peternakan dan Veteriner 2011, Fakultas Pertanian UNSRI. Palembang. Schalbroeck (2001).

Shcalbroeck. 2001. Toxicologikal evalution of red mold rice. DFG-Senate Comision on Food Savety. Ternak Monogastrik. Karya Ilmiah. Fakultas Peternakan Institut Pertanian Bogor, Bogor.

Tillman, A.D., H. Hartadi, S. Reksohadiprodjo, S. Prawirokusumo, dan S. Lebdosoekojo. 1991. Ilmu Makanan Ternak Dasar. Gadjah Mada University Press, Yogyakarta 